ISSN 1818-1295 elSSN 2616-6194

REPORTS OF MORPHOLOGY
Official Journal of the Scientific Society of Anatomists,
Histologists, Embryologists and Topographic Anatomists
of Ukraine
journal homepage: https://morphology-journal.com

\title{
Prognostic assessment of constitutional indicators influence on the indicators of personality traits of practically healthy women with different somatotypes
}

\author{
Andriievskyi I.I. ${ }^{1}$, Serebrennikova O.A. ${ }^{1}$, Bondar S.A. ${ }^{1}$, Shayuk A.V. ${ }^{2}$, Gunas I.V. ${ }^{1}$
}

${ }^{1}$ National Pirogov Memorial Medical University, Vinnytsya, Ukraine

${ }^{2}$ Zhytomyr Ivan Franko State University, Zhytomyr, Ukraine

\section{ARTICLE INFO}

Received: 30 July 2021

Accepted: 27 August 2021

UDC: $572.087: 159.922$

\section{CORRESPONDING AUTHOR}

e-mail: nolenole4@gmail.com Andriievskyi I.I.

\section{CONFLICT OF INTEREST}

The authors have no conflicts of interest to declare.

\section{FUNDING}

The work was financially supported by the National Pirogov Memorial Medical University, Vinnytsya, Ministry of Health of Ukraine (№ state registration: 0109U005544)
It is known that both genetic factors and environmental influences affect the development of the human body. This statement also applies to a person's personality, in the big five - the main features that make it up. The study of the relationship between physique and personality traits among a healthy population is very relevant and is a promising area for anthropology and psychology. The purpose of the work is to conduct a prognostic assessment of the influence of anthropo-somatotypological indicators on the personality indicators in practically healthy Ukrainian women without and taking into account the somatotype. Primary anthropo-somatotypological (anthropometry according to Bunak's scheme, Heath-Carter somatotype determination, Matiegka and American Institute of Nutrition weight composition) and personality indicators (determination of leading typological characteristics of temperament according to Eysenck, psychodynamic features of personality according to Spielberger and features of accentuated personality traits according to Shmishek, components of internality according to Rotter) of practically healthy Ukrainian women of the first mature age are selected from the data bank of materials of the research center of National Pirogov Memorial Medical University, Vinnytsya. Factor analysis was performed in the license package "Statistica 6.1". The main factors that indicate the association of personality traits of practically healthy Ukrainian women of different somatotypes with some anthropo-somatotypological indicators: mesomorphs - "the size of the girth and fat size of the body" and "the size of the longitudinal size of the body"; in ectomorphs - "the size of the girth of the body" and "the size of the fat size of the body"; in endo-mesomorphs - "the magnitude of the circumferential size of the body" and "the magnitude of the width of the mandible"; in representatives of the middle intermediate somatotype - "the magnitude of the longitudinal and circumferential dimensions of the body" and "the magnitude of SFT on the posterior surface of the shoulder." In the general group of women, it is impossible to single out the second factor that has a significant load. Analysis of the obtained relationships of interdependence of personality traits, which have the greatest prognostic value in terms of formation of human personality with anthropo-somatotypological indicators showed that women of different somatotypes identified interdependencies have certain features. Thus, the application of factor analysis made it possible to determine the most significant relationships of personality indicators with the constitutional parameters of the body in practically healthy Ukrainian women of different somatotypes.

Keywords: indicators of personality traits, indicators of body structure and sizes, somatotype, practically healthy women, factor analysis.

\section{Introduction}

The relevance of research related to the study of human mental health is growing steadily. Mankind is faced with new and new stressful events that radically change the usual way of life. An example of such an event is the COVID-
19 pandemic. In addition, we should not forget about the usual stressors associated with work, study and other social activities.

Up to $33.7 \%$ of the world's population suffers from anxiety 
disorders during their lifetime, and among this group of people the most common disorder is agoraphobia [5].

Eating schedules are also widespread, especially in European countries. Anorexia nervosa is found in 1 to $4 \%$, bulimia nervosa in 1 to $2 \%$ and subthreshold eating disorders in 2 to $3 \%$ of European women. Among these individuals, more than $70 \%$ have concomitant anxiety disorder, $40 \%$ of mood disorders and more than $20 \%$ are engaged in self-harm [12].

According to the $\mathrm{WHO}$, in 2015 , there were about 800,000 suicides worldwide, of which $78 \%$ occurred in lowand middle-income countries. In general, suicides account for $1.4 \%$ of all premature deaths in the world [4].

In total, the cost of treating and overcoming the effects of human depression alone is estimated by researchers at between $\$ 30.1$ billion and $\$ 51.5$ billion annually [13].

Mental health disorders place a heavy burden not only on the patients themselves but also on their families and the state as a whole. Thus, there is a need to study a person's personality, namely the main features that make it up (the so-called big five), not only in pathological conditions but also in the norm.

Various both external and internal factors affect the development of human personality. Thus, even toxoplasmosis infection has been shown to cause changes in the big five indicators [15]. The most promising, simple and proven method of research for predicting the characteristics of human personality is anthropometric [14, 18, 22, 23].

The purpose of the study is to conduct a prognostic assessment of the impact of anthropo-somatotypological indicators on the indicators of personality traits in practically healthy Ukrainian women without and taking into account the somatotype.

\section{Materials and methods}

Primary anthropo-somatotypological and personality indicators of practically healthy Ukrainian women $(n=101)$ of the first mature age (from 21 to 35 years) were selected from the database of materials of the research center of National Pirogov Memorial Medical University, Vinnytsya.

Committee on Bioethics of National Pirogov Memorial Medical University, Vinnytsya (protocol № 11 From 03.12.2020) found that the studies do not contradict the basic bioethical standards of the Declaration of Helsinki, the Council of Europe Convention on Human Rights and Biomedicine (1977), the relevant $\mathrm{WHO}$ regulations and laws Of Ukraine.

Anthropometric survey was conducted according to the scheme of V.V. Bunak [6]; somatotype determination according to the mathematical scheme of J. Carter and B. Heath [7]; determination of fat, bone and muscle components of body weight - according to the formulas of J. Matiegka [16]; in addition, the muscle component of body weight - according to the method of the American Institute of Nutrition (AIN) [19]. The following distribution of women by somatotypes was established: endomorphs - 5; mesomorphs - 33; ectomorphs - 22; ecto-mesomorphs 2 ; endo-mesomorphs - 22; the average intermediate somatotype - 17.

Individual-personal properties of the organism were determined with the help of personality questionnaires [9, 17]. The evaluation of the leading typological characteristics of temperament according to $G$. Eysenck included the definition (score): the indicator on the scale of extraversionintroversion (AZ_E), the indicator on the scale of neuroticism $\left(A Z \_N\right)$ and the indicator on the scale of insincerity $\left(A Z \_L\right)$. Determination of psychodynamic personality traits by C.D. Spielberger in the modification of Y.L. Khanin included the definition (score): situational (reactive) anxiety (SP_ST) and personal anxiety (SP_LT). Assessment of the severity and features of accentuated personality traits by G. Shmishek included the definition (score): indicator of accentuation of character of hyperthymic type (SH_G), indicator of accentuation of character of stuck type ( $\mathrm{SH} Z \mathrm{Z})$, indicator of accentuation of character of emotional type (SH_EM), indicator of accentuation of character of pedantic type (SH_P), anxiety type accentuation index (SH_T), cyclothymic type character accentuation index (SH_C), demonstrative type character accentuation index (SH_DM), excitatory type character accentuation index ( $\left.\mathrm{SH}_{-} \mathrm{V}\right)$, dysthymic type character accentuation index (SH_DC) and character accentuations of the exalted type (SH_EK). Determination of the components of internality by J. Rotter in the modification of E.F. Bazhin, S.O. Golinkina and O.M. Etkind included the definition (stan): the indicator of the scale of general internality of the level of subjective control (USK_1), the indicator of the level of subjective control in the field of achievements (USK_2), the indicator of the level of subjective control in the field of failures (USK_3), the indicator of the level of subjective control in the field of family relations (USK_4), the indicator of the level of subjective control in the field of educational (professional) relations (USK_5), the indicator of the level of subjective control in the field of interpersonal relations (USK_6) and the indicator of the level of subjective control in the field of health and disease (USK_7).

To conduct a prognostic assessment of the impact of anthropo-somatotypological indicators on the indicators of personality traits of practically healthy women used factor analysis, which was conducted in the license package "Statistica 6.1".

\section{Results}

For factor analysis, both in women of the general group and in the division into different somatotypes, the analysis included all indicators of personality and anthroposomatotypological parameters of the body that do not have negative values.

In the general group of women (without division into somatotypes), using the analysis of the "scree plot" [2], identified 3 separate factors (Fig. 1), for which the following main characteristics were established (Table 1). 
Given that the eigenvalues of all factors in the general group of women are more than 1, they all have the right to exist according to the first criterion of selection of factors. The total amount of variance is $33.70 \%$, but the second and third "parts" of the variance, which jump from the first, are almost indistinguishable from each other, so they can be abandoned (see Table 1). The calculated loads (correlation coefficients between the initial variables and the values of the factors [2]) confirm the impossibility to identify the second factor that has significant loads in the general group of women.

In women of mesomorphic somatotype using the "scree plot" were identified 3 separate factors (Fig. 2), for which the following main characteristics are established (Table 2).

Since the eigenvalues of all factors in women of mesomorphic somatotype are more than 1 , they have the right to exist according to the first criterion of selection of factors. The total amount of variance is $36.92 \%$. Given that the third "part" of the variance by jump differs from the first and second, it can be abandoned (see Table 2).

The calculated loads allowed to identify the most significant for each factor (greater than 0.750 ). It was found that the first factor in women of mesomorphic somatotype includes body weight, shoulder girth in a tense, unstressed state, forearm in the upper part, neck, waist and all chest girth, superficial conjugate, SFT on the thigh, all components of the somatotype, fat component body weight according to Matiegka and muscle component of body weight according to AIN, and the second - body length, height of suprasternal, pubic and acromial anthropometric points. To maximize the scatter of load squares, we used the Varimax method for each factor [2]. Comparing the results obtained in women of mesomorphic somatotype with the previous ones, it was found that in the first factor in women of mesomorphic somatotype among the most significant loads remained shoulder girths in a tense, unstressed state, neck, waist and all chest girths, thighs on the thigh, all components fat component of body weight according to Matiegka, as well as added SFT on the abdomen and side. In the second factor in women of mesomorphic somatotype among the most significant loads remained only the length of the body, the height of the thoracic, pubic and acromial anthropometric points, and the height of the acetabular anthropometric point was added.

Thus, in women of mesomorphic somatotype, the first factor can be defined as "the size of the girth and fat size of the body", and the second factor - "the size of the longitudinal size of the body".

The obtained results allow to determine and formalize the interdependence of personality indicators with anthropo-somatotypological indicators in practically healthy women of mesomorphic somatotype in the form of the following relationships: $y_{(A Z E E)}=-0.001 f_{1}+-0.341 f_{2} ; y_{(A Z N)}=-$ $0.188 \mathrm{f}_{1}+-0.143 \mathrm{f}_{2} ; \mathrm{y}_{(\mathrm{AZ} L \mathrm{~L})}=0.464 \mathrm{f}_{1}+0.185 \mathrm{f}_{2} ; \mathrm{y}_{(\mathrm{SP} S \mathrm{ST})}=-0.209 \mathrm{f}_{1}$ $+0.042 \mathrm{f}_{2} ; \mathrm{y}_{\left(\mathrm{SP} \_\mathrm{LT}\right)}=-0.230 \mathrm{f}_{1}+-0.096 \mathrm{f}_{2} ; \mathrm{y}_{(\mathrm{SH} G \mathrm{G})}=0.076 \mathrm{f}_{1}+-0.208 \mathrm{f}_{2}$; $\mathrm{y}_{(\mathrm{SH} Z \mathrm{Z})}=0.205 \mathrm{f}_{1}+0.010 \mathrm{f}_{2} ; \mathrm{y}_{\left(\mathrm{SH}_{-} E M\right)}=0.136 \mathrm{f}_{1}+-0.233 \mathrm{f}_{2} ; \mathrm{y}_{\left(\mathrm{SH}_{-} \mathrm{P}\right)}=-$

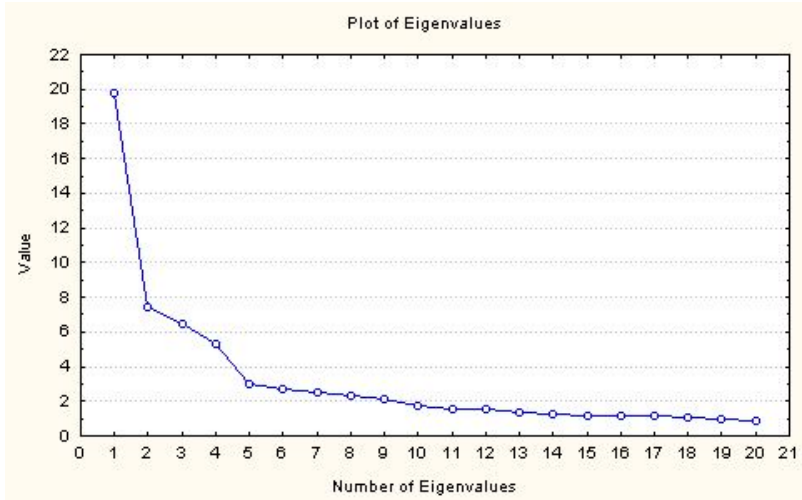

Fig. 1. Graph of selection of the number of factors using the "scree plot" in the general group of women.

Table 1. The results of primary data processing in the general group of women using factor analysis.

\begin{tabular}{|c|c|c|c|c|}
\hline & Eigenval & $\%$ total Variance & Cumul. Eigenval & Cumul.\% \\
\hline 1 & 19.79 & 25.05 & 19.79 & 25.05 \\
\hline 2 & 7.405 & 9.374 & 27.19 & 34.42 \\
\hline 3 & 6.510 & 8.241 & 33.70 & 42.66 \\
\hline
\end{tabular}

Notes: here and in after: Eigenval - eigenvalues; \% total Variance - \% of total variance; Cumul. Eigenval - the sum of eigenvalues; Cumul.\% - the accumulated percentage of variance.

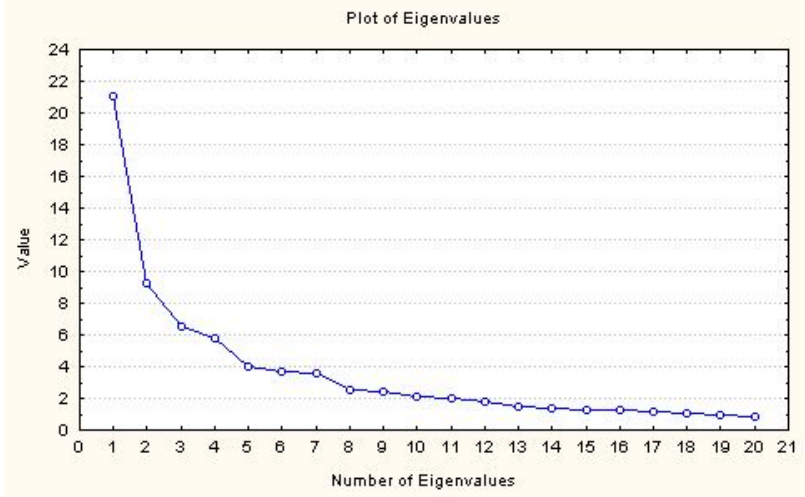

Fig. 2. Selection of the number of factors using the "scree plot" in women of mesomorphic somatotype.

Table 2. The results of primary data processing in women of mesomorphic somatotype using factor analysis.

\begin{tabular}{|c|c|c|c|c|}
\hline & Eigenval & \% total Variance & Cumul. Eigenval & Cumul.\% \\
\hline 1 & 21.05 & 26.65 & 21.05 & 26.65 \\
\hline 2 & 9.297 & 11.77 & 30.35 & 38.41 \\
\hline 3 & 6.575 & 8.322 & 36.92 & 46.74 \\
\hline
\end{tabular}

$0.180 f_{1}+-0.061 f_{2} ; y_{\left(S_{-} T\right)}=-0.184 f_{1}+-0.282 f_{2} ; y_{\left(S_{-} C\right)}=-0.250 f_{1}$ $+0.037 f_{2} ; y_{\left(S_{-} D M\right)}=0.097 f_{1}+-0.348 f_{2} ; y_{(S H-V)}=-0.190 f_{1}+-$ $0.340 f_{2} ; y_{\left(S_{-D C}\right)}=-0.059 f_{1}+0.152 f_{2} ; y_{\left(S_{-} E K\right)}=-0.417 f_{1}+-0.248 f_{2}$; $\mathrm{y}_{\left(\text {USK_1 }_{1}\right.}=0.087 \mathrm{f}_{1}+0.023 \mathrm{f}_{2} ; \mathrm{y}_{\left(\text {USK_ }_{2}\right)}=0.137 \mathrm{f}_{1}+0.282 \mathrm{f}_{2}$; $\mathrm{y}_{\text {(USK } 3)}=0.008 \mathrm{f}_{1}+0.236 \mathrm{f}_{2} ; \mathrm{y}_{\text {(USK } 4)}=0.031 \mathrm{f}_{1}+0.310 \mathrm{f}_{2} ; \mathrm{y}_{\text {(USK } 5)}=-$ $0.065 \mathrm{f}_{1}+0.041 \mathrm{f}_{2} ; \mathrm{y}_{\text {(USK_6) }}=-0.261 \mathrm{f}_{1}+0.042 \mathrm{f}_{2} ; \mathrm{y}_{\text {(USK_7) }}=-0.263 \mathrm{f}_{1}$ $+-0.089 f_{2}$; where, the factor $f_{1}-$ should be defined as "the size of the girth and fat size of the body" (the proportion of dispersion $-21.05 \%$ ) and is associated with the girth of the 


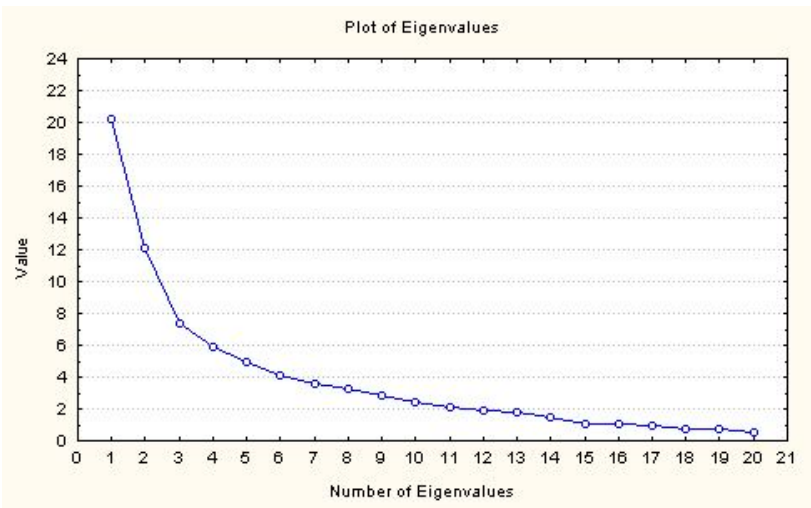

Fig. 3. Selection of the number of factors using the "scree plot" in women of ectomorphic somatotype.

Table 3. The results of primary data processing in women of ectomorphic somatotype using factor analysis.

\begin{tabular}{|c|c|c|c|c|}
\hline & Eigenval & \% total Variance & Cumul. Eigenval & Cumul.\% \\
\hline 1 & 20.17 & 25.54 & 20.17 & 25.54 \\
\hline 2 & 12.15 & 15.39 & 32.33 & 40.92 \\
\hline 3 & 7.402 & 9.370 & 39.73 & 50.29 \\
\hline
\end{tabular}

shoulder in a tense and unstressed state, neck, waist and all the girth of the chest, abdomen, sides and thighs, all components of the somatotype and fat component of body weight according to Matiegka; factor $\mathrm{f}_{2}$ - should be defined as "the value of the longitudinal dimensions of the body" (the proportion of variance $-9.30 \%$ ) and includes in its structure the length of the body, the height of the suprasternum, pubic, acromial and acetabular anthropometric points.

In women of ectomorphic somatotype using the "scree plot" were identified 3 separate factors (Fig. 3), for which the following main characteristics are established (Table 3 ). According to the first criterion of selection of factors, they all have the right to exist (the eigenvalues of all factors are more than 1). The total amount of variance in women of ectomorphic somatotype is $39.73 \%$. Given that the third "part" of the variance by jump differs from the first and second, it can be abandoned (see Table 3).

The calculated loads allowed to identify the most significant ectomorphic somatotype in women for each factor. It was found that the first factor in women of ectomorphic somatotype includes body weight, shoulder girth in a tense and unstressed state, forearms and legs in the upper part, neck, waist and thighs, intertrochanteric distance, muscle component of body weight according to Matiegka and AIN, and the second - the height of the acetabular anthropometric point, SFT on the abdomen and the fat component of body weight. The applied Varimax method allowed to maximize the scatter of load squares for each factor. Comparing the obtained results with the previous results, it was found that both in the first and in the second factor in women of ectomorphic somatotype the magnitude of the load did not change.
Thus, in women of ectomorphic somatotype, the first factor can be defined as "the size of the girth of the body", and the second factor - "the size of the fat size of the body."

The obtained results allow to determine and formalize the interdependence of personality indicators with anthropo-somatotypological indicators in practically healthy women of ectomorphic somatotype in the form of the following relationships: $y_{(A Z E)}=0.282 f_{1}+-0.445 f_{2} ; y_{(A Z N)}=-$ $0.492 \mathrm{f}_{1}+0.517 \mathrm{f}_{2} ; \mathrm{y}_{(\mathrm{AZ} L \mathrm{~L})}=-0.026 \mathrm{f}_{1}+0.010 \mathrm{f}_{2} ; \mathrm{y}_{(\mathrm{SP} S \mathrm{ST})}=-0.046 \mathrm{f}_{1}$ $+0.390 \mathrm{f}_{2} ; \mathrm{y}_{\left(\mathrm{SP} \_\mathrm{LT}\right)}=-0.038 \mathrm{f}_{1}+0.600 \mathrm{f}_{2} ; \mathrm{y}_{(\mathrm{SH} G \mathrm{G})}=0.103 \mathrm{f}_{1}+-0.651 \mathrm{f}_{2} ;$ $\mathrm{y}_{(\mathrm{SH} Z)}=-0.007 \bar{f}_{1}+0.045 \mathrm{f}_{2} ; \mathrm{y}_{\left(\mathrm{SH}_{-E M}\right)}=-0.11 \overline{2} \mathrm{f}_{1}+0.326 \mathrm{f}_{2} ; \mathrm{y}_{(\mathrm{SH} P \mathrm{P})}=-$ $0.436 f_{1}+-0.018 f_{2} ; y_{\left(S_{-} T\right)}=-0.582 f_{1}+0.306 f_{2} ; y_{\left(S_{-} C\right)}=-0.181 f_{1}$ $+0.559 \mathrm{f}_{2} ; \mathrm{y}_{(\mathrm{SH} \mathrm{DM})}=0.183 \mathrm{f}_{1}+-0.448 \mathrm{f}_{2} ; \mathrm{y}_{(\mathrm{SH} \mathrm{V})}=-0.182 \mathrm{f}_{1}+0.501 \mathrm{f}_{2}$; $\mathrm{y}_{(\mathrm{SH} D C)}=-0.29 \overline{3} \mathrm{f}_{1}+0.649 \mathrm{f}_{2} ; \mathrm{y}_{(\mathrm{SH} E \mathrm{EK})}=-0.22 \overline{4} \mathrm{f}_{1}+0.474 \mathrm{f}_{2} ; \mathrm{y}_{(\text {USK } 1)}=-$

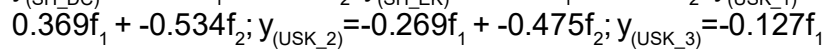
$+-0.375 f_{2} ; y_{(\text {USK } 4)}=-0.481 f_{1}+-0.317 f_{2} ; y_{(\text {USK } 5)}=-0.450 f_{1}+-$ $0.303 f_{2} ; y_{\text {(USK } 6)}=0.430 f_{1}+-0.132 f_{2} ; y_{\text {(USK } 7)}=-0.358 f_{1}+-0.024 f_{2}$; where, factor $f_{1}$ - should be defined as "the size of the girth of the body" (the proportion of variance - 20.17\%) and is related to body weight, shoulder girth in the tense and unstressed state, forearms and legs in the upper part, neck, waist and thighs, the muscular component of body weight according to Matiegka and according to AIN and intertrochanteric distance; factor $\mathrm{f}_{2}$ - should be defined as "the value of body fat size" (proportion of dispersion $12.15 \%$ ) and includes in its structure SFT on the abdomen, the fat component of body weight and the height of the acetabular anthropometric point.

In women of endo-mesomorphic somatotype using the "scree plot" were identified 3 separate factors (Fig. 4), for which the following main characteristics are established (Table 4). According to the first criterion of selection of factors, they all have the right to exist (the eigenvalues of all factors are more than 1). The total amount of variance in women of

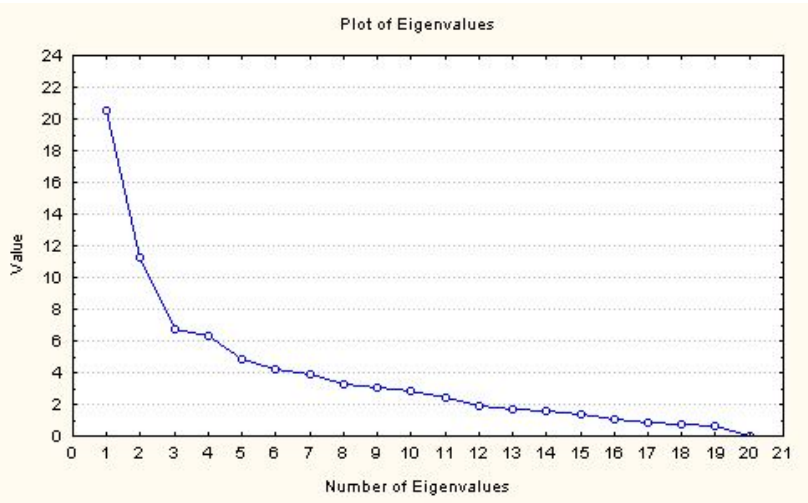

Fig. 4. Selection of the number of factors using the "scree plot" in women of endo-mesomorphic somatotype.

Table 4. The results of primary data processing in women of endo-mesomorphic somatotype using factor analysis.

\begin{tabular}{|c|c|c|c|c|}
\hline & Eigenval & $\%$ total Variance & Cumul. Eigenval & Cumul.\% \\
\hline 1 & 20.48 & 25.92 & 20.48 & 25.92 \\
\hline 2 & 11.26 & 14.25 & 31.73 & 40.17 \\
\hline 3 & 6.770 & 8.569 & 38.50 & 48.74 \\
\hline
\end{tabular}


endo-mesomorphic somatotype is $38.50 \%$. Given that the third "part" of the variance by jump differs from the previous ones, it can be abandoned (see Table 4).

The calculated loads allowed to identify the most significant endo-mesomorphic somatotype in women for each factor. It was found that the first factor in women of endo-mesomorphic somatotype includes body weight, height of the acromial anthropometric point, width of the distal epiphysis of the shoulder, hip and thigh circumference, SFT at the lower angle of the shoulder blade and shin, endomorphic component of the somatotype, bone and fat components of body weight according to Matiegka, and the second - the width of the mandible and the superficial conjugate. The applied Varimax method allowed to maximize the scatter of load squares for each factor. Comparing the results with the previous ones, it was found that in the first factor in women of endomesomorphic somatotype among the most significant loads were body weight, acromial anthropometric point height, hip and thigh girth and fat component of body weight according to Matiegka, and added shoulder girth in tension and unstressed state, the forearm at the top and the muscular component of body weight according to Matiegka. In the second factor, in women of endo-mesomorphic somatotype, only the width of the mandible remained among the most significant loads.

Thus, in women of endo-mesomorphic somatotype, the first factor can be defined as "the magnitude of the circumferential size of the body", and the second factor "the magnitude of the width of the mandible."

The obtained results allow to determine and formalize the interdependencies of personality indicators with anthropo-somatotypological indicators in practically healthy women of endo-mesomorphic somatotype in the form of the following relationships: $\mathrm{y}_{(A Z E)}=0.260 f_{1}+-0.116 f_{2} ; y_{(A Z N)}=-$ $0.159 \mathrm{f}_{1}+-0.286 \mathrm{f}_{2} ; \mathrm{y}_{(\mathrm{AZ} \mathrm{L})}=0.343 \mathrm{f}_{1}+0.134 \mathrm{f}_{2} ; \mathrm{y}_{(\mathrm{SP} S \mathrm{ST})}=-0.151 \mathrm{f}_{1}$ $+-0.084 f_{2} ; y_{\left(S P \_T\right)}=0.174 f_{1}+-0.433 f_{2} ; y_{\left(S_{-} G\right)}=0.125 f_{1}+-0.295 f_{2}$; $\mathrm{y}_{\left(\mathrm{SH}_{-} \mathrm{Z}\right)}=0.281 \mathrm{f}_{1}+-0.044 \mathrm{f}_{2} ; \mathrm{y}_{\left(\mathrm{SH}_{-} \mathrm{EM}\right)}=-0.293 \mathrm{f}_{1}+-0.220 \mathrm{f}_{2}$; $\mathrm{y}_{\left(\mathrm{SH}_{-} \mathrm{P}\right)}=0.115 \mathrm{f}_{1}+-0.315 \mathrm{f}_{2} ; \mathrm{y}_{\left(\mathrm{SH}_{\mathrm{T}}\right)}=-0.201 \mathrm{f}_{1}+-0.593 \mathrm{f}_{2} ; \mathrm{y}_{(\mathrm{SH} C \mathrm{C})}=-$

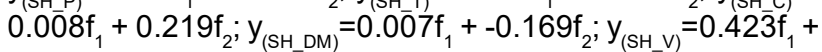
$0.263 f_{2} ; y_{(S H D C)}=-0.251 f_{1}+-0.190 f_{2} ; y_{(S H E K)}=-0.142 f_{1}+-$

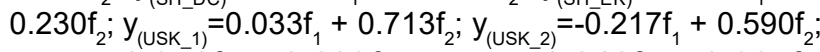
$\mathrm{y}_{\text {(USK_3) }}=0.356 \mathrm{f}_{1}+0.203 \mathrm{f}_{2} ; \mathrm{y}_{\text {(USK_4) }}=-0.246 \mathrm{f}_{1}+0.397 \mathrm{f}_{2}$; $\mathrm{y}_{\left(\text {USK }_{5}\right)}=0.156 \mathrm{f}_{1}+0.656 \mathrm{f}_{2} ; \mathrm{y}_{\left(\text {USK }_{6} 6\right)}=0.049 \mathrm{f}_{1}+0.235 \mathrm{f}_{2}$; $\mathrm{y}_{\text {(USK } 7)}=0.120 \mathrm{f}_{1}+0.360 \mathrm{f}_{2}$; where, the factor $\mathrm{f}_{1}$ - should be defined as "the size of the circumferential size of the body" (the proportion of variance $-20.48 \%$ ) and is related to body weight, shoulder girth in a tense and unstressed state, forearms in the upper part, thigh and thighs, muscles and fatty components of body weight according to Matiegka and height of acromial anthropometric point; factor $f_{2}$ - should be defined as "the value of the width of the mandible" (the proportion of variance - $11.26 \%$ ).

In women of medium intermediate somatotype using the "scree plot" were identified 3 separate factors (Fig. 5), for which the following main characteristics are established

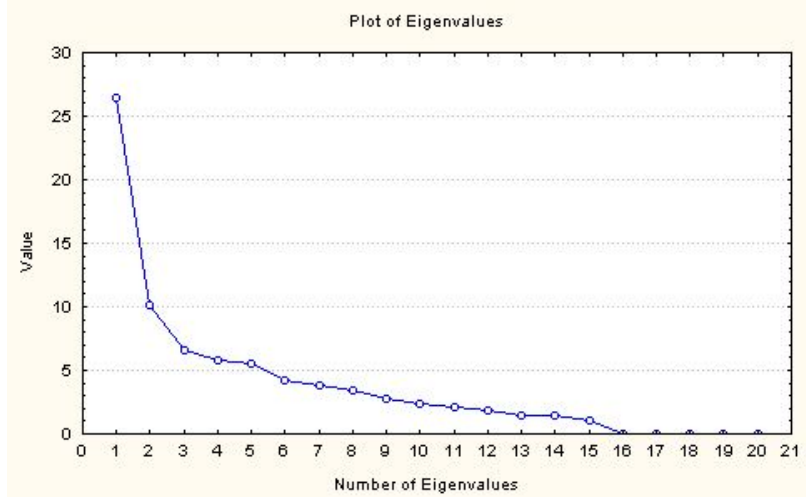

Fig. 5. Selection of the number of factors using the "scree plot" in women of intermediate somatotype.

Table 5. The results of primary data processing in women of intermediate somatotype using factor analysis.

\begin{tabular}{|c|c|c|c|c|}
\hline & Eigenval & $\%$ total Variance & Cumul. Eigenval & Cumul.\% \\
\hline 1 & 26.45 & 33.49 & 26.45 & 33.49 \\
\hline 2 & 10.12 & 12.81 & 36.57 & 46.30 \\
\hline 3 & 6.578 & 8.327 & 43.15 & 54.62 \\
\hline
\end{tabular}

(Table 5). According to the first criterion of selection of factors, they all have the right to exist (the eigenvalues of all factors are more than 1). The total amount of variance in women of medium intermediate somatotype is $43.15 \%$. Given that the third "part" of the variance by jump differs from the previous ones, it can be abandoned (see Table 5).

The calculated loads allowed to allocate in women of average intermediate somatotype for each factor the most significant. It is established that the first factor in women of middle intermediate somatotype includes the smallest width of the head, weight and length of the body, height of the suprasternum, pubic, acromial and acetabular anthropometric points, shoulder girth in a relaxed state, forearm in the upper part, neck, waist, waist on inhalation and at rest, intervertebral distance, superficial conjugate, muscle and bone components of body weight according to Matiegka and muscle component of body weight according to AIN, and the second - SFT on the back of the shoulder, muscle component of somatotype and an indicator of the accentuation of the character of the exalted type according to Shmishek. The applied Varimax method allowed to maximize the scatter of load squares for each factor. Comparing the obtained results with the previous ones, it was found that in the first factor in women of middle intermediate somatotype the magnitude of the load did not change, only the girth of the chest on exhalation was added. In the second factor in women of intermediate somatotype among the most significant loads remained only SFT on the posterior surface of the shoulder.

Thus, in women of intermediate somatotype, the first factor can be defined as "the magnitude of the longitudinal and circumferential dimensions of the body", and the second factor - "the magnitude of SFT on the posterior surface of the shoulder." 
The obtained results allow to determine and formalize the interdependence of personality indicators with anthropo-somatotypological indicators in practically healthy women of average intermediate somatotype in the form of the following relationships: $y_{(A Z E)}=0.260 f_{1}+-0.116 f_{2} ; y_{(A Z N)}=-$ $0.159 f_{1}+-0.286 f_{2} ; y_{(A Z L)}=0.343 f_{1}+0.134 f_{2} ; y_{(S P S T)}=-0.151 f_{1}$ $+-0.084 f_{2} ; y_{(S P ~ L T)}=0.174 f_{1}+-0.433 f_{2} ; y_{(S H G)}=0.125 f_{1}+-0.295 f_{2} ;$ $\mathrm{y}_{\left(\mathrm{SH}_{-} \mathrm{Z}\right)}=0.281 \overline{\mathrm{f}}_{1}+-0.044 \mathrm{f}_{2} ; \mathrm{y}_{\left(\mathrm{SH}_{-} \mathrm{EM}\right)}=-0.293 \mathrm{f}_{1}+-0.220 \mathrm{f}_{2}$; $\mathrm{y}_{(\mathrm{SH} \mathrm{P})}=0.115 \mathrm{f}_{1}+-0.315 \mathrm{f}_{2} ; \mathrm{y}_{(\mathrm{SH} \mathrm{T})}=-0.201 \mathrm{f}_{1}+-0.593 \mathrm{f}_{2} ; \mathrm{y}_{(\mathrm{SH} \mathrm{C})}=$ $0.008 f_{1}+0.219 f_{2} ; y_{(S H D M)}=0.007 f_{1}+-0.169 f_{2} ; y_{(S H}=0.42 \overline{3} f_{1}+$ $0.263 \mathrm{f}_{2} ; \mathrm{y}_{(\mathrm{SH} D D C)}=-0.251 \mathrm{f}_{1}+-0.190 \mathrm{f}_{2} ; \mathrm{y}_{(\mathrm{SH} E K)}=-0.142 \mathrm{f}_{1}+-$

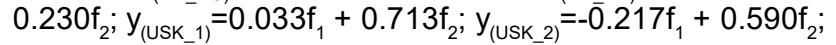
$\mathrm{y}_{\text {(USK_3) }}=0.356 \mathrm{f}_{1}+0.203 \mathrm{f}_{2} ; \mathrm{y}_{\text {(USK_4) }}=-0.246 \mathrm{f}_{1}+0.397 \mathrm{f}_{2}$; $\mathrm{y}_{\left(\text {USK_5 }_{1}\right)}=0.156 \mathrm{f}_{1}+0.656 \mathrm{f}_{2} ; \mathrm{y}_{\left(\mathrm{USK}_{-} 6\right)}=0.049 \mathrm{f}_{1}+0.235 \mathrm{f}_{2}$; $\mathrm{y}_{\text {(USK } 7)}=0.120 \mathrm{f}_{1}+0.360 \mathrm{f}_{2}$; where, the factor $\mathrm{f}_{1}$ - should be defined as "the magnitude of the longitudinal and circumferential dimensions of the body" (the proportion of dispersion - $26.45 \%$ ) and is related to body weight and length, height of the suprathoracic, pubic, acromial and acetabular anthropometric points, shoulder girths in unstressed waist, upper forearms, neck, waist, thighs and all chest, muscle component of body weight according to Matiegka and AIN, minimum head width, intertrochanteric distance, superficial conjugate and bone component of body weight according to Matiegka; factor $f_{2}$ - should be defined as "the value of SFT on the posterior surface of the shoulder" (the proportion of variance - 10.12\%).

\section{Discussion}

G. Armon and co-authors [3] surveyed 2664 and 1492 people with an interval of 4 years, during which they assessed sex, age, personality traits and anthropometric indicators. Statistical processing of the obtained results showed that honesty had negative correlations with three indicators of body weight; extraversion and neuroticism had positive correlations with two indicators of body weight. Among all the studied personality traits, neuroticism was most associated with an increase in body weight and openness with a decrease in women.

Examination of 756 children in the dynamics from birth to 2 years revealed the existence of a relationship between the indicators of head circumference and personality traits [8]. Higher head circumferences are associated with lower temperament control, lower speed and extraversion in boys.

Iranian scientists have found a relationship between body mass index, somatotype and temperament among military pilots [1].

After analyzing data from 3712 adults, the researchers found an interdependence between the high ratio of waist circumference to thighs and deficits in episodic memory and executive functions [10].

M. Hintsanen and others [11] using linear regression analysis found that higher search for new and lower dependence on reward are associated with higher values of BMI $(p<0.05)$. In another study, regression analysis found a significant association between EQ-5D (VAS) scores, harm avoidance and waist-to-height ratio, life event assessment (SRRS), and visceral fat percentage in women, and reward dependence and cooperativeness and ratio. waist circumference and height in men [20].

The study of young people revealed a relationship between neuroticism in women and extraversion in men and increased body weight. These relationships were similar in different racial and ethnic groups of the sample [21].

Using factor analysis, we found that in practically healthy Ukrainian women of different somatotypes often associated with indicators of personality are the following constitutional factors: in mesomorphic somatotype - "the size of the girth and fat size of the body" (share of variance - 21.05\%) and "longitudinal body size" (the share of variance - $9.297 \%$ ); in representatives of the ectomorphic somatotype - "the size of the circumferential size of the body" (the share of dispersion - 20.17\%) and "the value of fat body size" (the share of dispersion - $12.15 \%)$; in representatives of the endo-mesomorphic somatotype - "the value of the circumferential size of the body" (the proportion of variance - $20.48 \%$ ) and "the value of the width of the mandible" (the proportion of variance $-11.26 \%$ ); in the representatives of the middle intermediate somatotype - "the magnitude of the longitudinal and circumferential dimensions of the body" (the proportion of variance $-26.45 \%$ ) and "the value of SFT on the posterior surface of the shoulder" (the proportion of variance $-10.12 \%$ ). In the general group of women (without division into somatotypes) it is impossible to single out the second factor which has considerable loadings.

As a result of the factor analysis of the received interrelations of interdependence of personality features indicators which have the greatest prognostic value from the point of view of formation of the person (AZ_N, SP_ST, SP_LT, SH_EM, SH_T, SH_DM, SH_V, USK_1, USK_5 and USK_7) with anthropo-somatotypological parameters of the body of practically healthy Ukrainian women of different somatotypes found:

- in women of mesomorphic somatotype - with increasing shoulder girth in a tense, unstressed state, neck, waist and all girth of the chest, SFT on the thigh, abdomen and side, endomorphic component of the somatotype and fat component of body weight according to Matiegka degree of probability SP_ST, SP_LT, SH_T, SH_V, USK_5 and USK_7 decreases, and indicators SH_EM, SH_DM and USK_1 - increases; with increasing body length, height of the suprasternum, pubic, acetabular and acromial anthropometric points, the probability of growth of $A Z \_N$, SP_LT, SH_EM, SH_T, SH_DM, SH_V and USK_7 decreases, and indicators SP_ST, USK_1 and USK_ $\overline{5}$ increases;

- in women of ectomorphic somatotype - with increasing body weight, shoulder girth in a tense and unstressed state, forearms and legs in the upper part, neck, waist and thighs, muscle component of body weight according to Matiegka 
and AIN degree of probability of growth indicators $A Z \_N$, SP_ST, SP_LT, SH_EM, SH_T, SH_V, USK_1, USK_5 and USK_7 decreases, and SH_DM increases; with an increase in SFT on the abdomen and fat component of body weight according to Matiegka, the degree of probability of growth of SH_DM, USK_1, USK_5 and USK_7 decreases, and

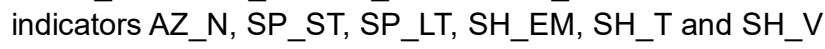
- increases;

- in women of endo-mesomorphic somatotype - with increasing body weight, shoulder girth in a tense and unstressed state, forearms in the upper part, thighs and thighs, muscle component of body weight according to Matiegka, the degree of probability of increasing AZ_N, SP_ST, SH_EM and SH_T decreases, and indicators SP_LT, SH_DM, SH_V, USK_1, USK_5 and USK_7 increases; with increasing width of the mandible, the degree of probability of growth of AZ_N, SP_ST, SP_LT, SH_EM, SH_T and SH_DM decreases, and indicators SH_V, USK_1, USK_5 and USK_7 - increases;

- in women of intermediate somatotype - with increasing body weight and length, height of the suprasternum, pubic, acromial and acetabular anthropometric points, shoulder girth in a relaxed state, forearm in the upper part, neck, waist, thighs and all chest, muscular and muscular components of body weight according to Matiegka and

\section{References}

[1] Ahmadi, M.A., Kashfi, S.M., \& Heydarian, M. (2020). The relationship between temperament, somatotype and some anthropometric variables and prevalence of musculoskeletal injuries in military pilots: A cross-sectional study. Jorjani Biomedicine Journal, 8(4), 42-53. doi: 10.52547/ jorjanibiomedj.8.4.42

[2] Antomonov, M.Yu. (2018) Математическая обработка и анализ медико-биологических данных [Mathematical processing and analysis of biomedical data]. К.: МИЦ "Мединформ" - К.: MIC "Medinform".

[3] Armon, G., Melamed, S., Shirom, A., Shapira, I., \& Berliner, S. (2013). Personality traits and body weight measures: Concurrent and across-time associations. European Journal of Personality, 27(4), 398-408. doi: 10.1002/per.1902

[4] Bachmann, S. (2018). Epidemiology of suicide and the psychiatric perspective. International Journal of Environmental Research and Public Health, 15(7), 1425. doi: 10.3390/ ijerph15071425

[5] Bandelow, B., \& Michaelis, S. (2015). Epidemiology of anxiety disorders in the 21st century. Dialogues in Clinical Neuroscience, 17(3), 327-335. doi: 10.31887/ DCNS.2015.17.3/bbandelow

[6] Bunak, V. V. (1941). Антропометрия: практический курс [Anthropometry: a practical course]. М.: Учпедгиз - М.: Uchpedgiz.

[7] Carter, J.L., \& Heath, B.H. (1990). Somatotyping - development and applications. Cambridge University Press.

[8] Dupont, C., Castellanos-Ryan, N., Séguin, J.R., Muckle, G., Simard, M.N., Shapiro, G.D., ... \& Lippé, S. (2018). The predictive value of head circumference growth during the first year of life on early child traits. Scientific reports, 8(1), 1-9. doi: 10.1038/s41598-018-28165-8

[9] Eliseev, O.P. (2010). Практикум по психологии [Workshop muscle component of body weight according to AIN degree of probability of increase of indicators AZ_N, SP_ST, SP_LT, SH_T, SH_DM, USK_1, USK_5 and USK_7 decreases, and indicators SH_EM and SH_V - increases; with increasing SFT on the posterior surface of the shoulder, the degree of probability of AZ_N, SP_ST, SP_LT, SH_EM, SH_T and USK_5 growth decreases, and indicators SH_DM, SH_V, USK 1 and USK 7 - increases.

Thus, the application of factor analysis made it possible to determine in Ukrainian women of different somatotypes the most significant relationships of personality indicators with the constitutional parameters of the body.

\section{Conclusions}

1. In practically healthy Ukrainian women of different somatotypes, the main constitutional factors that have a significant impact on the indicators of personality traits have been identified during the factor analysis.

2. Analysis of the obtained relationships of interdependence of constitutional parameters of the body in women of different somatotypes with indicators of personality traits that have the greatest prognostic value in terms of formation of human personality showed that the representatives of different somatotypes identified interdependencies have their own characteristics.

on psychology]. СПб: Питер. - St. Petersburg: Peter

[10] Hartanto, A., \& Yong, J.C. (2018). Measurement matters: higher waist-to-hip ratio but not body mass index is associated with deficits in executive functions and episodic memory. PeerJ., 6, e5624. doi: $10.7717 /$ peerj.5624

[11] Hintsanen, M., Jokela, M., Cloninger, C.R., Pulkki-Råback, L., Hintsa, T., Elovainio, M. ... Keltikangas-Järvinen, L. (2012). Temperament and character predict body-mass index: A population-based prospective cohort study. Journal of Psychosomatic Research, 73(5), 391-397. doi: 10.1016/ j.jpsychores.2012.08.012

[12] Keski-Rahkonen, A., \& Mustelin, L. (2016). Epidemiology of eating disorders in Europe: prevalence, incidence, comorbidity, course, consequences, and risk factors. Current Opinion in Psychiatry, 29(6), 340-345. doi: 10.1097/ YCO.0000000000000278

[13] Kessler, R.C. (2012). The costs of depression. Psychiatric Clinics, 35(1), 1-14. doi: 10.1016/j.psc.2011.11.005

[14] Kummer, S., Dalkner, N., Schwerdtfeger, A., Hamm, C., Schwalsberger, K., Reininghaus, B. ... Reininghaus, E. (2021). The conscientiousness-health link in depression: Results from a path analysis. Journal of Affective Disorders, 295, 12201228. doi: 10.1016/j.jad.2021.09.017

[15] Lindová, J., Příplatová, L., \& Flegr, J. (2012). Higher extraversion and lower conscientiousness in humans infected with Toxoplasma. European Journal of Personality, 26(3), 285291. https://doi.org/10.1002/per.838

[16] Matiegka, J. (1921). The testing of physical efficiency. Am. J. Phys. Antropol., 2(3), 25-38. doi: 10.1002/ajpa.1330040302

[17] Raigorodskii, D.la. (2004). Практическая психодиагностика. Методики и тесты [Practical psychodiagnostics. Methods and tests]. Самара: Издательский дом "БахрахM" - Samara: Publishing House "Bahrah-M". 
[18] Serebrennikova, O.A., Gunas, V.I., Klimas, L.A., Marchuk, I.A. \& Shayuk, A.V. (2019). Prognostic evaluation, using factor analysis, the influence of dermatoglyphic indices on indices of personality traits. Reports of Morphology, 25(1), 12-18. doi: 10.31393/morphology-journal-2019-25(1)-02

[19] Shephard, R.J. (2005). Body composition in biological anthropology. Cambridge University Press, Cambridge, UK; New York. https://www.nhbs.com/body-composition-inbiological-anthropology-book

[20] Slepecky, M., Kotianova, A., Prasko, J., Majercak, I., Kotian, M., Gyorgyova, E. ... Sollar, T. (2019). Relation of personality factors and life events to waist/height ratio and percentage of visceral fat in women and men. Psychology Research and
Behavior Management, 12, 499-511. doi: 10.2147/ PRBM.S214303

[21] Sutin, A.R., \& Terracciano, A. (2016). Five factor model personality traits and the objective and subjective experience of body weight. Journal of Personality, 84(1), 102-112. doi: 10.1111/jopy. 12143

[22] Sutin, A.R., Kerr, J.A., \& Terracciano, A. (2017). Temperament and body weight from ages 4 to 15 years. International Journal of Obesity, 41(7), 1056-1061. doi: 10.1038/ijo.2017.62

[23] Tsenkova, V.K., Carr, D., Coe, C.L., \& Ryff, C.D. (2012). Synergistic effect of neuroticism and body mass index on glucose metabolism in nondiabetic adults. Psychotherapy and Psychosomatics, 81(5), 327-328. doi: 10.1159/000337413

\section{ПРОГНОСТИЧНА ОЦІНКА ВПЛИВУ КОНСТИТУЦІОНАЛЬНИХ ПОКАЗНИКІВ НА ПОКАЗНИКИ ОСОБЛИВОСТЕЙ ОСОБИСТОСТІ ПРАКТИЧНО ЗДОРОВИХ ЖІНОК РІЗНИХ СОМАТОТИПІВ}

Андрісвський I.І., Серебреннікова О.А., Бондарь С.А., Шаюк А.В., Гунас І.В.

Відомо, що як генетичні фактори, так і вплив зовнішнього середовища впливають на розвиток тілобудови людини. Дане твердження так само стосується і особистості людини, тобто великої п'ятірки - основних рис, що ї̈ становлять. Дослідження взаємозв'язку між показниками тілобудови та особливостей особистості людини серед здорового населення має значну актуальність іє перспективним напрямком для антропології та психологіі. Мета роботи - провести прогностичну оцінку впливу антропо-соматотипологічних показників на показники особливостей особистості практично здорових українських жінок без та з урахуванням соматотипу. Первинні антропо-соматотипологічні (антропометрія за схемою Бунака, визначення соматотипу за схемою Heath-Carter, визначення компонентного складу маси miла за Matiegka ma Американським інститутом харчування) та показники особливостей особистості (визначення провідних типологічних характеристик темпераменту за Eуsenck, психодинамічних особливостей особистості за Spielberger, вираженості та особливості акцентуйованих рис особистості за Shmishek, складових інтернальності за Rotter) практично здорових українських жінок першого зрілого віку відібрані з банку даних матеріалів науково-дослідного центру Вінницького національного медичного університету ім. М.І.Пирогова. Факторний аналіз проведений в ліцензійному пакеті "Statistica 6.1". Bcтановлені головні чинники, які свідчать про асоційованість особливостей особистості практично здорових українських жінок різних соматотипів з деякими антропо-соматотипологічними показниками: у мезоморфрів - "величина обхватних і жирових розмірів тіла" i "величина поздовжніх розмірів тіла"; у ектоморфрів - "величина обхватних розмірів тіла" $i$ "величина жирових розмірів тіла"; у ендо-мезоморфів - "величина обхватних розмірів тіла" і "величина ширини нижньої щелепи"; у представниць середнього проміжного соматотипу - "величина поздовжніх і обхватних розмірів тіла" $i$ "величина ТШжС на задній поверхні плеча". У загальній групі жінок виділити другий фрактор, що має значущі навантаження, неможливо. Аналіз отриманих взаємовідношень взаємозалежності показників особливостей особистості, які мають найбільше прогностичне значення 3 точки зору формування особистості людини з антропо-соматотипологічними показниками, показав, що у жінок різних соматотипів виявлені взаємозалежності мають певні особливості. Таким чином, застосування фракторного аналізу надало можливість визначити найбільш значущі взаємозв'язки показників особливостей особистості з конституціональними параметрами тіла практично здорових українських жінок різних соматотипів.

Ключові слова: показники особливостей особистості, показники будови та розмірів тіла, соматотип, практично здорові жінки, фракторний аналіз. 